\title{
TOURISM AND THE LOCAL ECONOMY IN ECUADOR
}

\section{INTRODUCTION}

The following text is a preliminary report of the joint field research ${ }^{1}$, carried on in Ecuador, in June and July of 1997, as a part of the Department's of Regional Studies on Latin America research project on "The role of tourism in social and economic life of local rural societies in Ecuador".

The project aims at defining the relevance of tourism both for the social life and the spatial organization of rural societies. Several small towns and localities situated in the most important tourist regions of the country had been selected for the study on the basis of the existing literature. Once in Ecuador, the list of chosen localities was discussed with local academics and tourist organizers ${ }^{2}$. Detailed studies concerning tourist attractions, access facilities, tourist installations and the movement of visitors were done in localities concentrated in 5 areas - each one specialized in a different kind of tourism (Fig. 1). In all of them, tourist services are the main form of economic activity, but in each one the local population employment depends on it in different degree. The visitors movements' features such as the

${ }^{1}$ In the field research trip carried on in June and July 1997 participated the following persons: Celina Kuzak, Bogumiła Lisocka-Jaegermann, Jerzy Makowski, Maria Skoczek, Urszula Zulawska from the Institute of Developing Countries, Faculty of Geography and Regional Studies at the University of Warsaw, and Elżbieta Siarkiewicz from the Iberian Department of the same University.

${ }^{2}$ Among the most important publications consulted by the authors while preparing the project were the works of David Schaller (1996) and Rolf Wesche (1995), the several authors' book Propuestas de Politicas de Turismo (1995), as well as Lonely Planet guide book Ecuador and Galapagos Islands (Rachowiecki, 1995). Mr. Eduardo Fiallo, an Ecuadorian living in Warsaw has helped us a lot with his valuable advice.

In Ecuador we consulted the selection of the study areas with dr Gunther Reck, dean of the Department of Environmental Sciences of the University of San Francisco de Quito, and advisor of the Ministry of Environment of the Republic of Ecuador, as well as with representants of local communities from Mindo and Alto Napo, participating in the National Meeting on the "Communitary Participation in Ecotourism "organized by the Ecuadorian Association of Ecotourism, 30 of June and 1 of July 1997. We owe our gratitude to all our consultants. 
number of tourists, their origin, top and low seasons, the character of the visits, vary according to the area, as well as the level of development of the tourist infrastructure. To some extend it is due to different periods of time in which tourist services have been performed on larger scale in each one of the places. The participation of the local population in the organization of tourism, and directly in the services, is the common feature of all the areas mentioned.

The presentation of the case studies centers on tourism seen as a factor boosting the local economic and social life. We pretend to show ecuadorian tourism diversity, in order to verify our preliminary assumption that tourism of different kinds has different impact on the local societies' life.

\section{TOURISM IN ECUADOR. GENERAL CHARACTERISTICS}

Although considering its attractiveness for tourists, Ecuador is one of the most interesting Latin American countries, in the past it did not have much significance within the international tourist flow. In the 80-ties, 250000 to 350000 tourists were visiting the country each year. In 1990 the number surpassed 400000 and rose quickly to more then 500000 in 1996 (WTO). This rapid increase of the number of visitors is related to the phenomena of rising popularity of alternative tourism and its active promotion in the country. Ecuador's natural diversity - rich fauna and flora ${ }^{3}$ as well as anthropogenic features such as the folklore of the indigenous and afroecuadorian population and the colonial architecture heritage, attract to the country visitors interested in ecological tourism, folkloric (cultural) tourism, qualified tourism and agrotourism, among other. In the period of the last years the national tourists flows are increasing as well, as one of the effects of intense urbanization, the state educational policy and the promotion of active forms of leisure by the media.

The activity of tourist publicity and information on the state level is carried on by the Ministry of Tourism and the Ecuadorian Corporation of Tourism (CETUR). A large number of tourist agencies ${ }^{4}$, non-governmental

${ }^{3}$ In Ecuador $20000-25000$ of plants species were identified, 324 species of mammals, 1560 of birds (the fourth country in the world after Colombia, Peru and Brazil), 402 species of reptiles, 406 of amphibians, 710 of river fish and 1300 species of snails (Parques Nacionales $y$ Otras Areas Protegidas del Ecuador Ecociencia 1994, cited according to Propuestas.... (1995) p. 28).

${ }^{4}$ Metropolitan Touring, KLEINTOURS and ETNOTUR are among the most important travel agencies, with main offices in Quito and regional branches in capitals of the majority of provinces. Local agencies specialize in ecological tourism, especially the Amazon trips. They have offices in Baños (Tungurahua province) - on the route Quito- Ambato- Puyo known as the gateway to the Amazon, as well as in some of the Amazon towns, such as Puyo, Tena, Misahuallí, Coca (Puerto Francisco Orellana), Lago Agrio (Nueva Loja). 


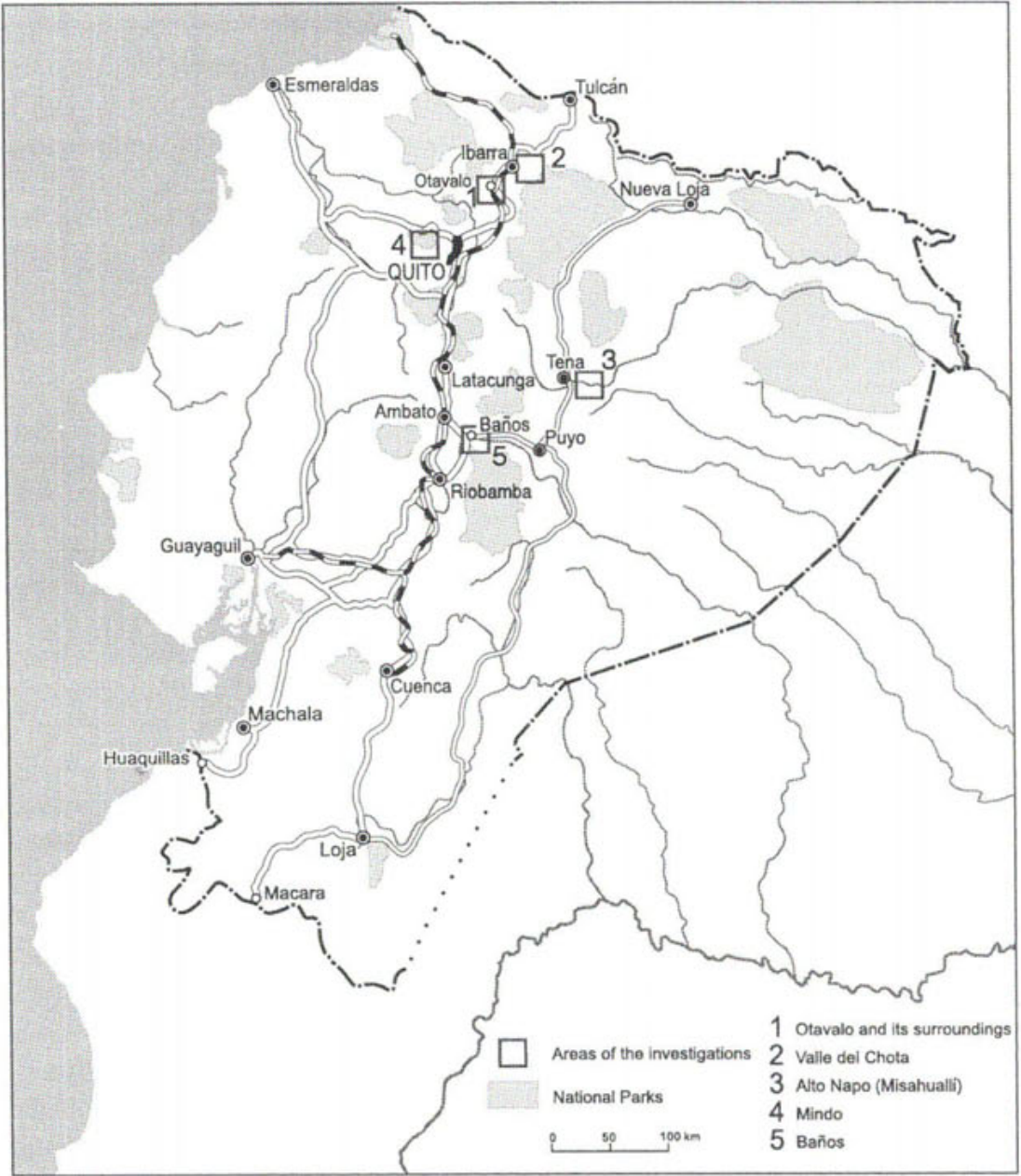

Fig. 1. Five main field research areas.

organizations $s^{5}$ and more and more often, local communities ${ }^{6}$ are involved in the organization of tourist flow and services. The latter, as partners of foreign and national investors are becoming owners of hotel and gastro-

5 There are several NGOs that promote ecological tourism, e.g. Fundacion Natura Fundación Ecuatoriana para la Conservación de la Naturaleza, EcoCiencia - Fundación Ecuatoriana de Estudios Ecológicos that, among other activities, provide training for the participants of ecoturist projects from The Amazon and the Coastal regions.

${ }^{6}$ The text presents an example of a local indigenous communities organization for tourism development called RICANCIE - Indigenous Network of Communities of the Upper Napo for Intercultural Co-Living and Ecoturism - see the Alto Napo section. 
nomic installations, and they offer related services such as transportation providing access to the tourist areas.

The development of foreign and national tourism in the recent years have been accompanied by the growth of the number of hotels and gastronomic installations, outside of the main urban centers. Private investors building elegant inns (hosterias) in attractive zones, and the amazonian Indian communities providing lodging services in cabins (cabañas) in their areas offer particular examples of the process. The hotel installations mentioned developed only at the end of the 80-ties and the increase of their number as well as variety of forms and quality contribute to the functional diversification of the rural areas and their activization, being an interesting form of the new tourist spaces.

As it was already mentioned, in the 90-ties the number of foreign and national tourists has increased. Thanks to the promotion of alternative tourism and the opening of new tourist areas, the visitors movement is distributed during the whole year, although particular groups come to Ecuador in the specific periods.

Among the foreign tourists the Colombians are the ones that come in the biggest number, visiting mainly the northern part of the country - between the colombian-ecuadorian border and Quito. Many are trade tourists who buy crafts and other hand made products, such as the leather clothes in Cotacachi. Their visits concentrate in November and December (shopping before Christmas), and in March ( before Easter). According to the numbers of visitors Colombians are followed by North Americans, Europeans (mainly from Germany, Holland and France), Japanese as well as by tourists coming from Israel, New Zealand and Australia. Summer holidays on the northern hemisphere (July and August) as well as November, December and January are the top season periods, when travelers visit the Amazon and the Andean regions. Some of them come to Ecuador mainly with the purpose of seeing its rich flora and fauna (such is the case of bird watchers) and they spend several days in nature reserves or national parks. Others climb the andean volcanos' peaks (Cotopaxi, Chimborazo, Tungurahua). Many take part in andean countries tours, that pass through Ecuador on the way to Colombia or Peru. Perhaps the highest is the number of tourist visiting Galapagos Islands ${ }^{7}$.

National tourism concentrates mainly in the coast, in the provinces of Guayas, Manabí and Esmeraldas (beach related tourism), and in some centers situated close to the Andean cities. The new recreational area of Valle de Chota (Imbabura province) and as well as in the traditional tourist resort in Baños (Tungurahua province) are among the most visited moun-

${ }^{7}$ In 1996 Galapagos Islands were visited by 600000 tourists, among them 450000 foreigners, according to the Galapagos National Park data, based on the number of entrance permits sold (Informe Galapagos 1996-1997, 1997, diagram 26, p. 19). That means that more then $50 \%$ of tourists coming to Ecuador visit Galapagos. 
tain centers. It is worth mentioning that apart from individual tourist, there are also groups of children and youths coming to those areas on the school trips organized towards the end of the course ( mid June till midJuly). Some andean indigenous communities also organize weekend trips for their members.

\section{TOURISM AS A FACTOR OF LOCAL ECONOMY DEVELOPMENT}

\section{OTAVALO AND ITS SURROUNDINGS}

Otavalo is situated in the northern part of Ecuador (north of Quito) between the mountain ranges of Cordillera Real (Cordillera Oriental) and Cordillera Occidental, on 2500 m.a.s.l. The town's scenery is dominated by two mountains: Cotacachi on the north west $(4939 \mathrm{~m}$ a.s.l.) and a lower peak Imbabura on the north east separated by the Otavalo valley. The climate of the region belongs to the group of tropical mountain climates and is characterized as a subtropical dry one (Martyn D., 1995) ${ }^{8}$.

The Otavalo region offers picturesque landscapes shaped by nature (San Pablo lakes, 3 Mojanda lakes, Cuicocha lake in volcanic crater of Cotacachi, Peguche cascade, forests on the steep slopes of the mountains) and human activities (indigenous villages, a mosaic of fields on the gentle sides of the volcanos). The Otavalo canton is inhabited by the Otavalo Indians - the most famous indigenous group of Ecuador ${ }^{9}$. They preserve ethnic traditions - the women are always dressed in the traditional way - men wear their traditional clothes only on Sundays but they are easily noticeable because of their long hair worn as a single pigtail. Local festivities such as Fiesta del Yamor - in September or Saint John the Baptist celebrated together with a tradition of pre-colombian origin - the Inti Raymi on 24th of June are another markers of tradition, that attract tourist to Otavalo.

The Saturday market is undoubtfully the biggest Otavalo tourist attraction. As it has two functions - it is a craft market for tourists and a local market where the inhabitants of the region sell and buy their crops, animals, food, clothes and other essentials. The tourist visit it not only to buy but also to observe, take photographs or film. Every Saturday, hundreds of foreigners: individuals as well as numerous groups organized by all the tourist agencies from Quito come to the market. National tourist also visit the market. Commercial middlemen from other parts of the country among them representants of other indigenous groups of the Sierra region

8 The names of climatic zones and types, that appear in the present article are based on W. Okolowicz climatic regionalization of the world published in the book of D. Martyn (1995).

9 Instituto Otavaleño de Antropología established in 1975 develops research and educational programs concerning the Otavalo culture. It publishes its own review Sarance. 
arrive on regular basis. Intermediaries from other andean countries (Colombia, Peru, Bolivia) also sell on the market.

Otavalo tourist infrastructure is rich and diverse: the town has more then 50 hotels and boarding houses (pensiones) of different quality, travel agencies, restaurants, bars, cafes, folk music clubs (peñas), art galleries and more then 140 craft shops offering products from all over Ecuador and from the andean countries (Meisch, 1995). The whole-sale shops being often outlets of the workshops as well as the agencies transporting goods to "any country of the world" offer their services both to visitors and to the local retailers. On the famous "Plaza de Ponchos" — open air market with stalls, the weavers from Otavalo and surrounding villages sell their products to tourists.

The majority of Otavalo tourist installations (lodging, gastronomic and commercial services) are owned by the Otavalo inhabitants - Ecuadorians (Indians and mestizos) and some foreigners who live in Ecuador.

Concentration of visitors in particular week days and seasons can be easily observed in Otavalo. The tourist come on Friday afternoons or Saturday mornings - to see the Saturday market. Local festivities (in the end of June, September and December/January) also intensify the visitors' flow.

In Otavalo there are several local tourist agencies offering one-day trips to nearby villages. The program includes a visit to a craft workshops (weaving and spinning in Peguche, leather workshops in Cotacachi, sweater knitting in Carabuela), a stop in one of the mountain centers on the lakes, in the evening - participation in local festivities. The development of the tourist installations in the nearby villages and towns (Peguche, Cotacachi) as well as in the countryside places of attractive landscapes (on the lakes) is an interesting phenomenon. Country inns (hosterias), offering a variety of active forms of spending time, such as horse riding, mountain biking, trekking, are a new element of the local scenery. The owners - local Indian families or newcomers, including foreigners, pay much attention to the preservation and promotion of local traditions (architectural forms, building materials, design, local festivities and the local food on the menu). This aspect of their activities was usually stressed by our interviews' respondents and it usually appears in the information leaflets published and distributed by the inns (often both in Spanish and English).

Multi-occupation that consists in combining within a family several kinds of activities such as the work in agriculture, crafts manufacturing, trade, seasonal or long-term labour migration is the most characteristic feature of Otavaleños social and economic behavior (Meier, 1996; Lema, 1995). Intense activities within the organization of the tourist infrastructure and development of tourist services that could have been observed among the Otavalo for several years, seem to be the present day form of that strategy, one more kind of employment adopted by the indigenous population. Otavaleños have been able to adjust their manufacture production to the needs and tastes of tourists and other foreign clients; they are 
creating the so called 'tourist product' on the basis of their tradition, preserving however their own identity.

The words of one of the members of the Otavalo society, the author of Los Otavalos. Cultura y tradición milenarias, German Patricio Lema, seem to confirm the importance of tourism for the indigenous population of the region:

"Tourism has brought benefits to the economic development of Otavalo, making possible that the contemporary youths study, travel outside the country taking their message, their language, their music, their weavings and their clothes to other parts" (Lema, 1995, p. 117).

\section{VALLE DEL CHOTA}

Valle de Chota is the name of a new tourist resort established in the andean province of Imbabura, in the northern part of the country. It is situated on Panamerican Highway, $35 \mathrm{~km}$ from the province capital Ibarra, in the Valley of Chota River - a tributary of Mira River that flows into the Pacific Ocean, on the Colombian territory. The resort stretches out on the altitude of 1500-1600 $\mathrm{m}$ a.s.l. in the climatic range of 'tierra templada'. Its climate is a subtropical dry one, belonging to the tropical climates zone (Martyn, 1995). The climate seems to be the most important natural attraction of the place.

Valle del Chota is an interesting place from the ethnographic point of view. The majority of inhabitants are Afro-Ecuadorians, descendants of slaves brough in the Colonial period to sugar cane plantationes owned by the Jesuits ${ }^{10}$. The Chota Blacks are known for their musical traditions the so called 'music de la Bomba' is an interesting mixture of african and andean rhytms. The local music groups can be heard in Chota. They also play for tourists in the local inns.

The first tourist oriented investment was made in Chota in 1986 when the restaurant El Oasis was built. Within several years it was transformed in a big complex Hostería El Oasis (Oasis Inn) with 120 beds in elegant cabins, 2 restaurants, 3 snack bars, a disco, an ice-cream cafe and several swimming pools which are a big attraction within the dry and dusty area of this part of Chota valley. One of the pools is equiped with a huge slide, another with waves-making machine. There are several sport installations in the area surrounded by well kept green gardens. The complex has an open, wooden bus (chiva) that takes tourists for trips outside (to the nearby village of Ambuqui) and a cart-train for children. It employs 30 people on regular basis, and some 40 seasonal workers (among them the construction workers building new cabins and improving the pools).

${ }^{10}$ The Center for Afro-Ecuadorian Culture in Quito conducts research on Valle del Chota culture as well as documents its folklore 
When in the early 90-ties El Oasis began to attract tourists, new complexes were built close to it. There are five smaller inns in the valley: Aruba - a 1st category inn, Jordán, El Eden, Tierra del Sol - 2nd category ones, and the smallest - 3rd category Fabricios. Among all the six, the inns have 350 beds. All of them have restaurants and swimming pools surrounded by gardens, although visitors staying in smaller inns use El Oasis swimming pools.

The Valle del Chota inns are visited by three different groups of clients. On summer weekends people come from Quito $(170 \mathrm{~km}$; 3 hours trip by bus) to enjoy the warmth and the swimming pools. Foreigners (North Americans and Europeans) visit the place in the period between August and September, usually staying for several days on trips organized by agencies that work together with the inns. Between mid June and mid July, on week days, the resort is invaded by children from Quito, Tulcán, and Ibarra who come on the school trips, organized as a celebration of the end of the school year. (At the time of our visit on Friday, 20 June there were 1500 children on the grounds of El Oasis. Other inns were also full of school children.) One day stay in Valle del Chota resorts is usually included within the program of 'The Imbabura province tour' prepared by the travel agencies.

The Valle del Chota inhabitants have participated in the developing tourist sector of the place only in a limited way. The majority of people employed by the inns come from Ibarra; only some of them live in the nearby villages of Chota and Carpuela situated in the valley. As the inns cater full services, on the Panamerican Highway, close to them there is only one chinese restaurant (Chifa China), one food store and two or three wooden fruit stalls. Close to the inns, ambulant local vendors (women and children) sell obo fruits - the most important commercial crop in the nearby Ambuquí valley. Stalls selling cheap crafts and sweets in front of the entrance to El Oasis must get a license from the inn and their number is limited. Their owners come from outside the place.

Valle del Chota is a tourist enclave within the agricultural landscape of the Chota River valley, created by initiative of external investors. It offers its services to foreign, mainly North American, European and Colombian clients and to the middle class, better off national tourists coming from other parts of the country. The prices of lodging and meals are relatively high in comparison with other Andean inns. The participants of the school trips visit the place on special terms, and they usually do not stay overnight.

\section{ALTO NAPO}

Alto Napo is vast area situated in the upper Napo River basin, in the north-eastern Ecuador, comprising the eastern slopes of Cordillera Real of Ecuadorian Andes between the Equator and the $130^{\circ} \mathrm{S}$ (Cordillera de 
Huacamayos and Cordillera de Galeras), and the adjacent part of the Amazon Lowland.

The area belongs to the zone of tropical climates with the warm and very humid one in the lowland part, up to $1000 \mathrm{~m}$ a.s.l., corresponding to tierra caliente climatic vertical zone, and the mountain subtropical climate (above the altitude of $1000 \mathrm{~m}$ ) with the characteristic vertical zones of tierra templada, and tierra fría.

The major part of the Upper Napo basin is covered by forests, which in a significant part conserve their primary character. Tropical rain forest (selva) on the Amazon lowland, different types of tropical mountain forests (the cloud forests among them)on the Andean slopes reaching high altitude grassland and schrubland (páramo) are the main types of vegetation of the area. Nature and wildlife are the main tourist attraction of the area.

All of the Napo Province is scarcely populated ( according to 1990 census there were 103387 people living on $33930 \mathrm{~km}^{2}$ ). The Upper Napo population consists of the indigenous groups (among them the Quichua lowland indians are the majority) and the colonists of mestizo or Spanish origin. Tena, the province capital, is the starting point for the majority of Amazon trips. Well communicated with Quito, with the population of 8000 inhabitants (1996 data of Consejo Provincial de Napo) it has twenty hotels, more then ten restaurants, bank branches, two taxi cooperatives, several travel agencies and is served by nine bus transport companies. Misahualli - on the left side of the Napo River, $13 \mathrm{~km}$ east of Tena, is the second town of the area and another starting point for the trips.

Among the tourist infrastructure existing in the region there are private - national and foreign owned agencies and lodging installations, NGOs related enterprises as well as tourist programs developed and operated by the local indigenous communities. The local population is involved in the activities of majority of them, being employed directly, or providing services such as guidance, transportation or lodging on their own.

The numerous travel agencies operating in Tena and in Misahuallí offer a variety of one to ten days lasting guided tours programs that in case of larger groups can be prepared according to the tourists interests and possibilities ${ }^{11}$.

Another kind of services, the cabin-based tourism (Wesche, 1995) is operated from outside the region. Packages sold by Quito travel agencies include a comfortable transportation, relatively high standard lodging in cabin complexes where the visitors enjoy "a leisurely program of activities" (Wesche, 1995, p. 23).

${ }^{11}$ A standard trip usually combines a canoe ride, a walk through the forest with a guide, a visit to an Indian family or/and to an Indian shaman at the minimum cost ranging between 25 to $35 \$$ per day per person. Sacha Tours f.e. offers $30 \$$ per day trips provided the group is at least a 5 persons one. Trips to see Pre-Columbian petroglyphs on large rocks and limestone caves that are another tourist attractions of the Tena region can be also arranged. 
Some of the local agencies such as Amarongachi Jungle Trips which is one of the biggest in Tena provide both kinds of services oriented towards different group of visitors.

Community based indigenous ecoturism ${ }^{12}$ appeared in the area in 1989, with the cabaña complex built by the Quichua community of Capirona. After their ecoturism project proved to be successful, RICANCIE - Indigenous Network of Communities of the Upper Napo for Intercultural Co-Living and Ecoturism was established in 1994. Twenty one communities joined the project by 1995 (Wesche, 1995), and thirty by July 1997 - but at the time of our visit only ten actively participated in it.

RICANCIE projects consist in a small scale, community controlled ecotourism aiming at "the conservation of the rain forest - and protecting the indigenous way of life". The organization has its office in Tena ${ }^{13}$ It offers one to eight days trips. Apart from the elements that appear in the majority of programs offered by travel agencies they give the tourist the chance of getting into closer contact with the local population.

The authors were able to visit three places managed by RICANCIE: the Runa Huasi cabins, the newest, easily accessible cabins built and managed by a group of Quichua families from Ahuano, a more remote community of Las Galeras, where the project had been suspended due to organization and management difficulties, and Rio Blanco where the tourist project is communal - cabins for tourists, situated $1 \mathrm{~km}$ down the river Huambuno from the community center were built and have been maintained during mingas ${ }^{14}$.

Close to 300 visitors among North Americans, Ecuadorians and Europeans came to Río Blanco in 1996 (the majority for 1 to 3 days stays) to enjoy trips to the jungle, a visit to medicinal plants garden and the cultural exchange program including a craft show and a dance and music evening

12 According to the definition of Advisory State Commission on Environment (CAAM), formulated in 1994, the term 'ecoturism' should be understood in Ecuador as "the displacement towards natural areas for the sake of understanding the culture and natural history of the entire local environment, with necessary precautions in order not to alter the integrity of local ecosystems and cultures, and to generate economic opportunities that make possible the natural areas conservation directed in the way that benefits local communities, that share the responsibility for the environment with tourist operators and visitors".

${ }^{13}$ RICANCIE (Calle Atahualpa y 9 de Octubre \#35, Casilla \#243, Tena, Napo) offers programs usually discussed with the visitors, that in just one day can walk for four hours through the forest with an indigenous Spanish speaking guide showing a variety of medicinal plants and explaining their use, visit the Amazoonico (a rehabilitation center where animals confiscated by Ecuadorian customs are being adapted to the life in the wild), observe gold panning on the Napo River shore, and the process of preparing chicha in the community, see the gardens, and the blow-gun use demonstrations in the village, talk about the local life with the host family in the cabins, the guides and the people they meet. A one day overnight stay, costs $35 \$$ per person including the program.

${ }^{14}$ Minga - traditional communal work characteristic for indigenous communities in the andean region. 
that the community spends with the visitors. The project was analyzed by David Schaller (1996). According to his study some of the tourist satisfied with the nature program, found the cultural one too 'staged' and not 'authentic' enough. Considering that the community was established only in 1975 we can assume it is in the process of creation of its own tradition ${ }^{15}$. Our impression was that the show, as well as the crafts demonstration were an opportunity for the local people to get together (some of the people who live outside the community center also show up).

Contrary to what Schaller writes the community members we talked to understood the sense of the project, stating in our conversations that they saw it as the best possibility of improving their lives and guaranteeing a better future to their children. They stress the necessity of preserving the primary forest situated between the community and the Napo River, and to keep the place clean (there is a compost-pool and thrash bins in the village, and the difference, in comparison to the nearby community of the same size we saw was striking). The forest and the place attract tourists and the revenue they bring although still heavily reinvested, has already made possible many improvements that people do appreciate. (Investments such as communal motor boat used for the transportation of tourists, but also crops and products that must be purchased at Punta Ahuano Friday market or horses, carrying the crops to the river, were made on this basis. The community built a new community house that was to be inaugurated in July 1997). The indigenous ecoturism project has been successful in several communities - but it also brings many risks to the local people. Their involvent in the preservation of the rain forest and the self reliance in management of ecoturism are seen by many decision makers as optimistic premises for the future of both the forests and the Quichua people.

\section{MINDO}

Mindo is a small village in the Pichincha province, only $25 \mathrm{~km}$ along a straight line north west from Quito, situated on the Canchupi river, in a scenic valley, within the area of transition between the western slopes of the Andes and the coastal lowland. On the altitude of $1250 \mathrm{~m}$ a.s.l. it has a milder climate then the humid and hot Coast and it is much warmer then the harsh climate of the Sierra.

The biggest Mindo attraction is the area's biodiversity. 600 species of birds (49 species of hummingbirds, 51 of tanagers (Emberizidae), 61 of flycatchers (Tyrannides) make the bird watchers flock to the area. Lavish

${ }^{15}$ During the folkloric show one of the community members tells the story of its establishment and development, and there is a quichua welcome song made for the visitors; a dance illustrating the Quichua Indians conflicts with Huaorani Indians is also performed. 
forest vegetation, the climate, as well as the possibility to bath in the rivers, draw the week-end visitors from Quito, for whom now the access is much easier since the new road Quito-Calacali-Nanegalito-Los Bancos-La Independencia has been opened. There is one bus a day from and to Quito and 2 buses on weekends. There are also 2 buses to Santo Domingo de los Colorados.

The population of the parish is of mixed origin - the local people distinguish among the old inhabitants - of indigenous, Afro-ecuadorian and mestizo descent and the newcomers, immigrants from the province of Loja that came to the place in the $60 \mathrm{~s}$, and the recent newcomers from Quito, who want to invest in the place, expecting it will grow as an important tourist resort. The place with 1700 inhabitants (1990 including the town and the parish) has ten hotels of different standard, including two high standard inns (Hostería El Carmelo inaugurated in 1994, and Mindo Gardens in 1993). The biggest ones are owned by quiteños, while the local ones are much smaller and offer lower standards.

The concept of ecoturism is also widely used in Mindo, by the majority of organizations and private tourist operators. The existence of the forest reserve "Bosque Protector Mindo Nambillo" with 19,200 ha is an important element of the tourist activities. It is managed by a community based Ecological Corporation "Amigos de la Naturaleza de Mindo", according to 1988 agreement with INEFAN (National Institute of Forestry, Natural Areas and Wildlife). The Corporation develops the education, control over and management programs, seeks funding and maintains contact with INEFAN. It also operates The Environmental Education Center (CEA), where nature trails, guided tours and lodging for 50 people are provided.

Five thousand people visited the Mindo forest in 1995 coming from Germany, US, France, Colombia, and the Ecuadorian Sierra cities (Quito, Ambato). More then half of them used lodging services of one of the hotels (Izurieta, 1995).

Although the Mindo community has made significant effort to control the local tourist resources and limit the access of travel agencies from Quito to the area, Thomas Perreault (1996) detected in Mindo "significant conflicts of interests and differences of perception (...) among local groups competing for the tourist revenue" (p. 172). The Corporation membership (twenty persons at the time of our stay) has been changing as a result of management style that was not accepted by all the members. Fundación Pacaso and Pacaso established by some former Corporation members initiated a guided tours service, and another former members offer private lodging and guiding services. Our observations confirm that opinion. Although there is no doubt tourism is bringing profits to the place creating some work places (apart from the hotels there are three bars in the village center, several people work as guides) and the market for agricultural products of the area (food shops, fruit stalls and products sold to hotel restaurants), the benefits the community has had as a whole are still limited. 
Probably, because of that reason,"it is still crucial that local people are convinced that birding and ecotourism are much better long-term sources of income then agriculture and cattle - ranching" as the local bird watchers guide Vinicio Perez states (Lyons, 1997). The communal activity seems to be fragmented and there is no coordination between the private investors that came to Mindo, such as the big inns owners and the local agents. The land ownership seems to be another problem. As the access to the Reserve is restricted the guides take visitors to private forest or pass through the private land provoking constant disputes over adequate payments.

\section{BAÑOS}

A town of 15000 inhabitants, Baños is one of the popular tourist resorts in the Ecuadorian Andes, situated at the altitude of $1800 \mathrm{~m}$ a.s.l., nearly at the feet of Tungurahua Volcano in a picturesque valley od Pastaza River cutting through the Cordillera Real on her way to the Amazon basin. The town and its surroundings enjoy mild climate characteristic for tierra templada. Apart from landscapes, Baños counts with thermal springs coming from the base of the nearby volcano, streams and waterfalls (Cabellera de la Virgen, Inés María, Agoyán) supplied in water by the snow on the peaks of Tungurahua and El Altar. Thanks to their existence swimming pools and baths have been built being one of the major tourist attractions of the place.

Situated on the important Ambato-Puyo road, Baños is also a gateway from the Sierra to the Amazon lowlands. It is well communicated with major cities and major routes, with comfortable bus connections to Quito (3,5 hours, vía Ambato),Ríobamba ( 2 hours) and Puyo - the capital of Pastaza province.

It has also been an important religious pilgrimages center to the Sanctuary of a miraculous La Virgen de Agua Santa. However during the last years it transformed itself into a dynamic tourist resort visited by Ecuadorians and foreigners. Every year several thousands of tourists come to the place. Ecuadorians spend in Baños their weekends (during our stay on the weekend 28/29 of June we could observe members of indigenous Sierra communities coming by buses to see the waterfalls, visit the sanctuary and the Zoo in the outskirts of the town (Ecozoológico San Martín). The national tourists also spend holidays here. Foreigners (North Americans and Europeans) come to Baños to relax and stay for some days or treat the town as a convenient starting point for trips to the Amazon or for the mountain trekking.

More then ten travel agencies specialized in ecological tours to the Amazon, or organizing as well trekking trips to the mountains located their offices in Baños.

The development of tourist installation in the town in the 80s and in the 90 s was a work of both the local people and of the immigrants coming from the Sierra cities and towns, mainly from Quito and Ambato. There are more 
then fifty hotels and lodgings in the town and in the area (Rachowiecki, 1992, Welcome to Baños. The Alternative Tourists Guide Map) Some of them belong to foreigners. The majority of hotels have their own bars and/or restaurants, some organize horse trips, bike trips and longer guided tours to the Sierra Indian villages or to the Amazon, as well as trekking trips to the mountains.

Independent gastronomic establishments also increased in number. Several restaurants serve national dishes and the majority international food.

Retail commercial establishments also cater to tourists needs. Along Rocafuerte, one of the main streets, tens of craft shops sell ecuadorian as well as peruvian, bolivian, colombian and venezuelan crafts. Every second Saturday a craft Salasaca ${ }^{16}$ market is organized where the handmade tapestries made of wool dyed in native vegetable- based pigments and "showing the influence of Pre-Colombian mythology", are sold.

Carvings from the balsa wood - colorful birds, fishes and other animals are the popular craft sold to the tourist and exported to Venezuela, Colombia and less often to Europe and the US.The manufacturers, usually selling carvings in their workshops or in the specialized shops bring the wood from the coastal regions of Santo Domingo de los Colorados. Carving in tagua nuts (called "the vegetable ivory") are also made and sold in Baños. Sweets, and among them melloche - sugar cane mellow, produced directly in the shops and stalls close to the bus station are another local specialty.

A local transport is another tourist-oriented service offered in the town. There are buses to the Zoo and to the Agoyán waterfalls. There are also several funny cart trains (Dragon, Duckie, Romantic Caterpillar) taking people on trips around the town. Bike, motor-bike and horse rentals propose to visitors other transport possibilities. Baños is one of the few tourism - oriented towns in Ecuadorian Sierra, where the urban structure and services are directed nearly exclusively towards the satisfaction of the visitors demand. The changes within its spatial and functional organization that have taken place since 1980 are related to the priority given to tourism within the national economy development prospects. Nearby villages (Salcedo, Lligua, Runtún) also have the tourist functions although the services are dominated there by foreigners living in Ecuador.

\section{TYPES OF TOURISM AND THE LOCAL ECONOMIES}

The case studies presented above picture areas specialized in three types of tourism: cultural tourism in Otavalo, ecological one in Napo and Mindo and recreation tourism in El Chota Valley and Baños. The two first, cultural and ecological tourism, are strongly related to the life of local

${ }^{16}$ The Salasacas are the most important indigenous group of Tungurahua province. 
communities. The natural resources and cultural identity manifested by folklore are the major tourist resources.

The members of Otavalo society proved to be capable to benefit from the tourists interests in the local weaving production - using it for the sake of developing the manufacturing activities and creating new revenue resources, maintaining at the same time their own identity. The diversification of tourists visiting Otavalo creates room for investments in tourist services of different types, hotels and restaurants of different standards as well as diverse guided tours.

The spatial expansion of tourist installation towards the rural Otavalo areas in which the local society members participate actively, is another prove of the aptitude to use of possibilities of improving the level of life, granted by tourism.

The indigenous communities of Upper Napo included the tourism-oriented activities within their reality much later. Similar to the Otavalo case the foreign agents motivated them to the activity. However it is obvious that inhabitants of some of the communities took over the managements task and the revenues tourism brings to their areas. After only 3 years of RICANCIE activities - the economic and social impact on the local life can be observed. As in the case of Otavalo, it is controlled to considerable extend by the local people who through tourism activities seek chances for the preservation of their identity in the changing external conditions.

In Mindo, the large scale tourism services are dominated by people coming from outside the community, unable to create a consolidated local society. The newcomers, having financial possibilities of investments easily occupy space in the village and its surroundings. The tourism revenues in a very limited way contribute to the development of local economy. However, some of the local leaders, conscious of the situation hope to be able to consolidate the local inhabitants around ecotourist interests and to develop new form of activities catering to tourism, such as crafts, creating new sources of revenue.

The two last areas studied, both specialized in leisure tourism show different kinds of relation between tourism and local economy. In Baños tourist services are the main occupation of the local population, and the most important source of income. The town modernization observed during the last years is effect of tourism. In Valle del Chota new tourist resorts use only the land and water local resources. Their appearance has not changed much the local population social and economic behavior. Considering the low material level of the local life, as well as the lack of preparation it is obvious they inhabitants can not compete with the existing inns.

The preliminary results of the study confirm the idea that different kinds of tourism have different impact on the local rural societies. They also indicate the complexity of factors that determine possibilities of major or minor local participation, requiring further studies. The answer to the question concerning the prospects of development of both types of tourist services - the ones incorporated within the local social and economic life and 
the enclave tourist spaces such as Valle del Chota, or the elegant Mindo inn, can not be answered in the present report. We will be trying to discuss it in our following publications.

\section{REFERENCES}

1985, Datos agroclimatológicos, América Latina y el Caribe, FAO, Roma.

1995, Ecoturismo en el Ecuador. Trayectorias y desafíos, Colección sistematización de experiencias, 1, DDA/INTERCOOPERACION/UICN, Quito.

Gómez N., 1997, The Pocket Guide to Ecuador, Ediguas C. Ltda, Quito.

1997, Informe Galápagos 1996-1997, Fundación Natura y WWF, Quito.

Izurieta X., 1995, El Centro de Educación Ambiental de la Corporación Ecológica "Amigos de la Naturaleza de Mindo". Una experiencia de turismo ecológico promovida por una organización conservacionista comunitaria, in: Ecoturismo en el Ecuador, op.cit.

Lema A.G.P., 1995, Los Otavalos, Cultura y tradición milenarias, Ediciones ABYAYALA, Quito.

Lyons A.J., 1997, World Birdwatch, 19, 1, March 1997, 6-7, Mindo, Ecuador.

Martyn D., 1995, Klimaty kuli ziemskiej, PWN, Warszawa.

Meier P., 1996, Artesanos campesinos: desarrollo socio-económico y proceso de trabajo en la artesanía textil de Otavalo, Banco Central de Ecuador/OIA/Ediciones ABYA- YALA, Quito.

Meisch L.A., 1995, Gringas and Otavaleños. Changing tourist relations, Annals of Tourism Research, 22, 2, 441-462.

Pereault T., 1996, Nature Preserves and Community Conflict. A Case Study in Highland Ecuador, Mountain Research and Development, 16, 2, 167-175.

1995, Propuestas de Política de Turismo en las Areas Naturales Protegidas del País, Proyecto ECU/93/015 Protección a la Biodiversidad GEF/INEFAN, Quito.

Rachowiecki R., 1992, Ecuador and Galapagos Islands. A Travel Survival Kit, Lonely Planet Publications.

Schaller D.T., 1996, Indigenous Ecotourism and Sustainable Development: the Case Study of Rio Blanco, Ecuador, Department of Geography, University of Minnesotz (mimeo-INTERNET).

Wesche R. 1995, The Ecotourism Guide to the Ecuatorian Amazon. Napo Province, Tropical Research and Development, Univ. of Ottava, CEPEIGE, Quito. 